\title{
The Effects of Lecturers' Formal and Informal Talks on Students' Understanding of the Material in the Language Learning Process
}

\author{
Dewi Purwati \\ dpurwati94@gmail.com \\ Fakultas Tarbiyah, Institut Agama Islam Negeri Bone, Bone, Indonesia
}

Received: 25 April 2020 Accepted: 11 May 2020

DOI: 10.24256/ideas.v8i1.1315

\begin{abstract}
This research focused on investigating the effects of lecturers' formal and informal talks on students' understanding of the material. The aim of this research is to elaborate how the lecturer's talk in terms of its formal and informality could affect the students' understanding of the material delivered in the classroom. The researcher applied qualitative method to fulfil the aim and collected the data of the research by using three instruments which were classroom observations, recording of the teaching and learning process, and interview of the students. All teaching processes and interviews were recorded and transcribed and analysed using discourse analysis approach. The data was analyzed by adopting the six facets of understanding proposed by Wiggins \& McTighe (2018). The research was conducted at the first and fifth semester groups of English Study Program of IAIN Bone. The result shows that the lecturers used both formal and informal language alternately in teaching. The students preferred the lecturer to use informal language in delivering the material. According to them, using informal language made the students easier to understand the material delivered by the lecturer. They argued that teaching method and including the variation of lecturer's language in teaching gave a significant improvement to the students' achievement and understanding. The students fulfilled all the six facets of understanding based on the theory Wiggins \& McTighe (2018). It meant that the students had a complete understanding of the material delivered by the lecturers.
\end{abstract}

Keywords: Formal and Informal talks; lecturers' and students' talks, understanding.

\section{Introduction}

Communication between the lecturer and the students is essential in teaching and learning process, in order to performing effective learning. The lecturer does not only transfer the information and knowledge but also control the class. Students will consistently accept their teacher as a model of disposition, execution, character or talk. The language used by a lecturer is a fundamental perspective in 
The Effects of Lecturers' Formal and Informal Talks on Students' Understanding of the Material in the Language Learning Process

the classroom as a lecturer is the significant wellspring of information and guidance. It is significant for English lecturer to develop great correspondence with the students so as to accomplish the points of educating and learning process. A classroom does not just encourage students to improve their skills in learning English yet in addition a social network that assembles connections between members. The members of the English classroom comprise of lecturer and students. So as to cause the students to comprehend the material, correspondence among lecturer and students are significant in the educating and learning process (Wahyu, 2019).

The lecturer and the students cooperatively build a comprehension of each other and structure companionships by associating in significant correspondence and exercises. They convey to make the entire learning successful, beginning from opening the class, conveying showing material, posing inquiries, and overseeing practices in the classroom which decides if a class will be effective or not. It is fundamental for English lecturer to have great language utilization while conveying or delivering the material to the students. The utilization of fitting language will prompt the effective educating and learning process.

A term for kinds of the language used by the lecturer for instructions in the classroom is known as lecturer talk which is according to Xiao-Yan (2006) is an assortment of language which now and again is utilized by lecturer when they are in the instructing procedure. It is the distinction for every lecturer as each has his/her own teaching style. One of the fundamental things the lecturer should know is the utilization of formal and informal talks as one part of correspondence among lecturer and students in the classroom communication. Irvine (2001) characterized formality and informality as the ideas often utilized in the ethnography of correspondence, in sociolinguistics, and in social human sciences to portray social events and the conduct related with them. In the EFL classroom setting, the correspondence among lecturer and students is one of a social marvel which is not just only restricted formal circumstance yet in addition informal circumstance also.

Heylighen \& Dewaele (2002) who have clarified that these are a few reasons why individuals, remembering the lecturer for the classroom, would lean toward formal talks to relevant ones, or the other way around. They suggested that progressively formal language has less opportunity to be misconstrued by other people who do not have a similar setting as the sender, in spite of the way that it requires additional time, consideration, and psychological handling to be delivered and comprehended. Though Informal language is adaptable which implies implications move when the setting changes. This is especially helpful when wonders which will be portrayed are not accessible in the language yet. Thus, the interaction in EFL classroom cannot be avoided by formal and informal talks which are used among lecturer and students. The lecturer will dominantly use formal language to explain the material while the informal language used to attract students' attention. Whereas students prefer informal language to communicate with friends in order to gain information completely.

study conducted by Maghfiroh (2015) who discovered that the use of appropriate utterances of types of lecturer talk in creating an interactive learning classroom could develop students' speaking skill and students' understanding 
upon the material uttered by the lecturer. Moreover, Munawir (2017) attempted to recognize the formal and interactional highlights of teacher talk in the classroom connection during educating and learning process and uncovered that the teacher gave interactional input while tending to students in the classroom. This in the long run has a significant impact upon students' understanding of the material.

A study proposed by Sardi, Haryanto, \& Weda (2017), "the Distinct Types of Diction Used by the EFL Teachers in the Classroom Interaction", found that teacher likes to utilize informal phrasing or word decision in showing, for example, idiom, lingos, and slang. This is clearly in light of the fact that the teacher will in general give more consideration to the course book than straight doing an intuitive movement with the students. Likewise, considering the poor understudy level and intrigue constrained the teachers to communicate in Indonesian and nearby language substantially more than English in the class. It supports the finding of Heylighen \& Dewaele (2002) in their research which found that the separation in space, time or foundation between the questioners expanded, and when the speaker was male, thoughtful or scholastically instructed become the reason for a predominant utilization of formal language.

A research was conducted by Nemani \& Rasekh (2013) related to the students' language feature in classroom interaction. The finding shows that the social class raised the politeness degree of speech, while solidarity and power decreased the degree of politeness which means that the EFL learner is competent linguistically but incompetent in communicatively, the learner could not be considered to be an appropriate user of English in real various contexts.

\section{Formal and Informal Talks}

Richards \& Schmidt (2013) gives a meaning of formal speech as the sort of discourse utilized in circumstances when the speaker is cautious about articulation and selection of words and sentence structure. Francis \& Hunston (2013) attempted to decide the custom degree of a discourse by taking a gander at the recurrence of words and linguistic structures that are seen as either relaxed or cautious. Formal language is recognized by some exceptional consideration regarding structure where the speaker attempts to be near the standard structure and way to express the language. It is generally utilized by individuals on certain events, for example, functions, customs or assessments (Labov, 2004). In the interim, individuals likely want to utilize informal language when the circumstance is progressively common, for example, a discussion with loved ones, where speakers would pay more than the ordinary regard for structure on the off chance that they would need to ensure that their words are not misjudged.

Eggins \& Slade (2005) depicts the distinctions of formal and informal language with make a qualification of both. The description can be seen as following. 
Dewi Purwati

The Effects of Lecturers' Formal and Informal Talks on Students' Understanding of the Material in the Language Learning Process 2005)

Table 1 Formal and Informal Characteristics (Adapted from Eggins \& Slade ,

\begin{tabular}{ll}
\hline Formal Talk & Informal Talk \\
\hline Neutral lexis & Attitudinal lexis (purr \& snarl words) \\
\hline Formal lexis & Colloquial lexis \\
$-\quad$ Full forms & - Abbreviated forms \\
$-\quad$ No slang & - Slang \\
\hline Politeness phenomena & Swearing \\
\hline Careful turn-taking & Interruptions, overlap \\
\hline Titles, no first name & First names, nicknames, diminutives \\
\hline Incongruent mood choices & Typical mood choice \\
\hline Modal for deference & Modal to express probability \\
\hline Modal for suggestions & Modal to express an opinion \\
\hline
\end{tabular}

\section{Understanding}

Dewey (2008) clarified, to understand something is to look at it in its relationships to different things: to take note of how it works or capacities, what outcomes follow from it, what causes it. Wiske \& Breit (2013) proposed that understanding can also be defined as the capacity to think and act deftly with what one knows. That implies a comprehension of a subject is an adaptable activity capacity with accentuation on adaptability. Learning for comprehension resembles learning an adaptable presentation.

Wiggins \& McTighe (2018) proposed the theory of understanding consists of six facets. One can be said to understand if the student is able to provide:

1. Explanation with generalizations or principles, providing justified and systematic accounts of phenomena, facts, and data. Students can make meaningful relationships and provide illustrations.

2. Interpretation by telling meaningful stories, provide a revealing historical or personal dimension to ideas and events, make the object of understanding personal or accessible through images, anecdotes, analogies, and models.

3. An application which effectively uses and adapts what they know in diverse and real contexts.

4. Perspective by seeing and hearing points of view through critical eyes and ears, they can see the big picture.

5. An empathy which is indicated by finding something in what others might find unusual perceive sensitively on the basis of prior direct experience.

6. Self-knowledge through showing social awareness in perceiving the personal style, prejudices, projections, and habits of mind that both shape and impede our own understanding, being aware of what we do not understand and reflect on the meaning of learning and experience. 


\section{Method}

In this study, descriptive qualitative design was applied. Qualitative research involves gathering fundamentally textual information and inspecting it utilizing interpretive investigation (Heigham \& Croker, 2009). Furthermore, in this research, the researcher applied discourse analysis under the study of sociolinguistics as an approach to analyze the language, writing, speech, and conversation (verbal and nonverbal). Indeed, the researcher applied discourse analysis as a methodology that was suitable with the end goal of this research so as to get the depiction about the qualities of formal and informal talks utilized by lecturer and students and the impacts of formal and casual talk utilized by lecturer on students' understanding in EFL classroom. So as to get the information, the scientist did observation, recording, and interview. Lastly, the result of the data analysis was presented in description of words, not number.

In this research, the researcher used three instruments in collecting data, namely observation, recording, and interview. In this research, the researcher used act as non-participant observer to observe the entire phenomenon in the classroom whilst the teaching and learning interaction in English Study Program of IAIN Bone. Based on the observation, the researcher wrote a field notes to get the picture of classroom process, mainly about the formal and informal talks of lecturer and the students in the teaching and learning process. Furthermore, the researcher recorded all the interaction between teacher and students by using audio recorder. Recording was done during teaching and learning process. Interview is used to get the data about the effect of formal and informal talks of the lecturer and the students on the teaching and learning process. There are three types of interview. In this research, semi- structured interview was used because it was the focus in this study where the questions were organized, and it could be developed.

After collecting the data, the researcher described, identified, and classified the data. The researcher transcribed everything that happens during teaching and learning activity. After transcribing the data, the researcher coded the data. The researcher identified, selected, and classified the data based on the analysing need that is related to the topic of the research. After displaying and coding the data, the end of the analysis activity was conclusion drawing and verification. The data were interpreted.

\section{Results}

In this research, the researcher used interview which later was analyzed based on the six facets of understanding proposed by Wiggins \& McTighe (2018) to measure the students' understanding. The result of the interview shows that the lecturers used both formal and informal language in teaching. In fact, one lecturer taught using formal language dominantly while other lecturer used informal language dominantly based on students' admission. The following extract clearly shows the finding. 
The Effects of Lecturers' Formal and Informal Talks on Students' Understanding of the Material in the Language Learning Process

Extract 1: Comfort and active

The researcher asked whether the student prefers using formal or informal language in learning.

$Q$ : Which do you prefer whether formal or informal language in learning?

$A$ : $\quad$ In my opinion e.. saya lebih nyaman atau lebih mudah menangkap materi itu if the lecturer uses informal language.

In my opinion, e... I feel more comfortable or easier to catch up with the material if the lecturer uses informal language.

Extract 1 above indicates that the student preferred if the lecturer used informal language. She argued when the lecturer explained the material in informal language, she felt more comfortable and easier to catch the point. Besides, using informal language had a good impact on the students' understanding about the material. It was proven since the students successfully recalled the material that had been taught by the lecturer. The students even became more active during the lesson if the lecturer dominantly used informal language. The more detail of the data is delivered as following.

Extract 2: Enjoy and relax

The researcher asked whether the student prefers using formal or informal language in learning.

$Q$ : Which do you prefer formal or informal language when your lecturer is teaching?

A : Pada saat menjelaskan informal because we enjoy santai dalam mendengarkan pelajaran atau belajar.

(I prefer when he explains (the lesson) in informal language because we enjoy when we listen to the explanation and study)

Based on the extract 2 above, the student preferred informal language when lecturer delivered the material. She believed that all students would be relaxed and joyful in accepting material from the lecturer. Therefore, the material would be easy to understand.

Extract 3: Familiarity

$Q: \quad$ Is the material easy to understand whether in formal or informal language?

A : $\quad$ e.. informal karena Bahasa informal lebih sering kita dengar jadi lebih gampang masuk ke dalam karena lebih terbiasa. (e.. It is easier to understand the material in informal language because we are more familiar with the informal language and it makes us easier to catch up with the material).

Extract 3 above clearly shows the student's admission that informal language made them easy to understand the material. The informal language might help the student in comprehending the material easily because the words were familiar for them. Therefore, it is quite easy for them to catch the point of the lesson. Moreover, the informal language did not consist of sophisticated words. 
Extract 4: Deep understanding

$Q$ : Does he/she use formal and informal language alternately?

A : $\quad$ e.. if he speaks English, I think he always uses formal but if he doesn't but sometimes he explains-- if we don't understand if we can't catch what he meant so he uses simple sentence or e.. Bone dialects and I think that's informal and it's to make us more understand what he said.

In extract 4 above, the students stated that the lecturer would change her/his language into simpler forms if the students could not understand the material. It was proven by student's statement that the lecturer would alter the language into simple forms and regional term which made students would catch the point quickly.

There was one statement of students that could be considered as the positive effect of the use of formal talks in classroom interaction. The following extract would be the effects of lecturer's formal talks.

Extract 5: Improving students' ability in grammar

$Q$ : Which do you prefer whether formal or informal English in learning?

$A$ : I think I refer to infor-- eh formal because we can learn from e.. we can not just learn the material if he used formal but we can e.. train e.. our grammar too and listen what he said what about his grammar.

The extract 5 above clearly shows the positive effect of the use of formal talks in classroom interaction. The student perceived that she might get a bonus of lecturer's formal talks in order to improve her grammar and listening ability. Since the formal talks were constructed by full form and highlight words, the students were able to learn how to construct sentences grammatically. Besides, they also were able to train their listening skill while lecturer delivered the material.

A deeper analysis of students' understanding of the material was conducted by the researcher using six facets of understanding. If the students were able to explain, interpret, apply, have perspective, feel emphasized, and self- knowledge, it means the students had understood the material that had been taught by lecturers.

\section{Explanation}

The following extract shows the students' understanding of the material in term of explanation.

Extract 6: Explaining the material

Q : Would you like to tell me what your lecturer taught recently? Please, explain it briefly! (explanation)

A : Actually, in the first meeting it's easy to understand it's about language, linguistics, linguist. Language is e.. how to speak or using word adalah Bahasa. Language is using word form and then emm.. body language or something like that and then linguistics is something which is relating language and linguistics is a scientist of language then linguist is someone who masters skill in language... 
The Effects of Lecturers' Formal and Informal Talks on Students' Understanding of the Material in the Language Learning Process

The extract above shows that the student's understanding in term of explanation level. Based on the student's answer, she remembered what her lecturer had taught in the last three meetings. She successfully recalled the detailed material which indicated successful teaching of the lecturer.

\section{Interpretation}

The result of the interview showed that the students were able to successfully interpret the teaching material by using their own words. It can be seen at the extract as follow.

\section{Extract 7: Doubtful interpretation}

The researcher asked about the relationship of the material that the students had learned with their daily/social life.

Q : What is the relationship of the material you have learned with your $\mathrm{real} / \mathrm{social}$ life? (interpretation)

A : $\quad$ e.. mungkin berhubungan karena Bahasa itu terbentuk dari sejarah karena kita mempelajarinya jadi pasti berhubungan.

e.. there could be the relationship because the language was formed by the history and because we learn about it so it must be related.

The extract shows the student's understanding in term of interpretation. The question of the interview required the student to be able to corelate what they had learned from their lecturer with what they were going to face in their daily life. The answer of the student showed a bit hesitation about the relationship. However, she could correlate it that the language was formed by history, therefore there ought to be a correlation.

\section{Application}

Extract 8: Knowledge

The researcher asked whether the knowledge the students got will be useful for them and how useful it will be if it is.

Q : Do you think what your lecturer have taught will be useful for you? How? (application)

A : Oh yes bermanfaat sekali, terutama dari segi pengetahuan yah kita mengetahui oh ternyata sejarah linguistic seperti ini, mengalami perubahan sepeerti pada saat jaman Romawi Kuno sampai sekarang ini jadi sangat bermanfaat lah dan kemudian manfaatnya itu sendiri dalam kalo ilmu pengetahuan kita dapat membedakan bahwa e.. Bahasa yang digunakan pada zaman ini seperti ini kemudian mengalami perubahan lagi sampai sekarang ini.

(Oh yes, it is very useful, especially from the perspective of science, yeah, we know that actually the history of linguistics is like this, it changes like what happened in ancient Rome till nowadays so that it is very useful and the benefit itself by learning it is we can differentiate that e.. the language which was used at that time was like this and then, it changes again till nowadays.) 
The extract above shows the student's understanding in term of application. The question required the student to think whether the material would be useful and applicable. The student answered that the material would be useful to learn about the material as it made them to be able to know the changes of the language over time. It indicated that the student was able to effectively use and adapt what they knew in diverse and real contexts which meant the student understood the material in term of application.

Perspective

Extract 9 Informal language is more familiar

The researcher asked the student if the material is easy to understand whether in formal or informal language.

Q : Is the material easy to understand whether in formal or informal language? (perspective)

A : e.. informal karena Bahasa informal lebih sering kita dengar jadi lebih gampang masuk ke dalam karena lebih terbiasa. (e... It is easier to understand the material in informal language because we are more familiar with the informal language and it makes us easier to catch up with the material).

The extract indicates the student's understanding in term of having perspective. On the extract above, the student answered that it was easier to understand the material in informal language because it was familiar with them and make them easier to catch up. The student effectively showed her perspective about the language preference used by the lecturer in delivering the material.

\section{Feeling Empathy}

Extract 10: Honesty

The researcher asked the student about his/her friends' opinion upon the material and whether they understand or not.

Q : What do you think about your friends' opinion regarding the material and the technique? Do you think they can understand it? (empathize)

A : ...Dan karena kita hanya 18 orang dan perempuan semua jadi pasti kita jujur tidak, belum bu dan akan dijelaskan ulang.

(And also, because we are only 18 students in the class and all of them are women so we definitely will say "no, not yet Mam and it will be explained once more).

The extract indicates the student's understanding in term of feeling empathy. The question required the student to express what he/she thought about his/her friends' opinion upon the material and whether they understood or not. The student answered that her friend understood the material as the lecturer did not only explain the material but also gave some jokes and practiced it. Moreover, the lecturer also made sure all students understood the material by asking whether they understood or not. It showed that the student felt empathy about her friends which indicated that she understood the material. 
Dewi Purwati

The Effects of Lecturers' Formal and Informal Talks on Students' Understanding of the Material in the Language Learning Process

\section{Self-knowledge}

Extract 11: Audio visual

The researcher asked the student about his/her learning style or technique which can make them easier to understand the material.

Q : What learning style/ technique that you think is able to make you easy to understand the material? (self-reflection)

A : Audio visual seperti yang dilihat sehingga apa yah kita lebih nyaman, lebih mudah, tidak kaku atau tidak e.. tidak monoton lah jadi tidak hanya menulis saja, ada LCD ada audio visual juga sehingga bisa mudah dipahami. (It is audio visual like what we have seen. So that, how to say, we feel more comfortable, easier to catch up, do not feel rigid or do not e.. it is not monotonous so that it is not by writing the material but also using a projector, there is audiovisual to make it easier to understand)

The extract indicates the student's understanding in term of self-reflection. The student answered that she preferred to learn in audiovisual method because it could make them felt more comfortable, relaxed and easier to catch up. She liked if the lecturer used the projector in delivering the material. The student's answer showed that she was able to do self-reflection upon her learning preference.

\section{Discussion}

Based on the interview, the students informed that the lecturers used both formal and informal language alternately in teaching. The students preferred the lecturer to use informal language in delivering the material. According to them, using informal language made the students easier to understand the material delivered by the lecturer. However, variation between the formal and informal language is also needed to make the students gained more understanding as stated by Wolf-Wendel, Ward, \& Kinzie (2009). They argued that the teaching method and including the variation of lecturer's language in teaching gave a significant improvement to the students' achievement and understanding.

The more in-depth analysis showed that the students fulfilled all the six facets of understanding based on the theory by Wiggins \& McTighe (2018). It meant that the students had a complete understanding of the material delivered by their lecturers. In term of explanation, the students successfully recalled what they had learned. The students successfully explained all material which proved the previous finding that the students understand the material from the lecturers' explanation. In term of interpretation, the result of the interview showed that the students were able to successfully interpret the teaching material by using their own words. Meanwhile, the student was able to effectively use and adapt what they knew in real contexts which means she understood the material in term of application. The result of the interview also showed that the students successfully answered the question regarding having perspective. They showed their own perspective about the material delivered by the lecturer. Moreover, the students felt empathy upon whether their friends understand the material or not. They also 
usually discussed the material to get a better understanding. And the last, the students could do self-reflection on their own progress upon the learning process. It indicated that they understood the material as having self-reflection was one of the indicators of understanding.

\section{Conclusion}

It can be concluded that the students preferred when the lecturer used more informal language. When the lecturer used informal language, the students feel more comfortable and closer to the lecturer. The use of informal language also gives positive effect to the students particularly in avoiding a boring situation in the classroom. Moreover, the diction used by the lecturer in the informal talk were more familiar with the student which made the students easier to catch the meaning of what the lecturer tried to convey, as the students wanted the lecturer to explain the material in the language which was easy to understand. Moreover, the students successfully fulfilled all of the six facets of understanding proposed by Wiggins \& McTighe (2018). It meant that the students had a complete understanding of the material delivered by their lecturers. It can be said that the students understand the material uttered by the lecturers in the learning process.

\section{References}

Dewey, J. (2008). The Early Works, 1882-1898: 1882-1888. Early essays and Leibniz's new essays concerning the human understanding (Vol. 1). SIU Press.

Eggins, S., \& Slade, D. (2005). Analysing casual conversation. Equinox Publishing Ltd.

Francis, G., \& Hunston, S. (2013). Analysing everyday conversation. In Advances in spoken discourse analysis (pp. 129-167). Routledge.

Heigham, J., \& Croker, R. (2009). Qualitative research in applied linguistics: A practical introduction. Springer.

Heylighen, F., \& Dewaele, J.-M. (2002). Variation in the contextuality of language: An empirical measure. Foundations of Science, 7(3), 293-340.

Irvine, J. T. (2001). Formality and informality in communicative events. Linguistic Anthropology: A Reader, 189-207.

Labov, W. (2004). Ordinary events. Sociolinguistic Variation: Critical Reflections, $31-43$.

Maghfiroh, L. (2015). The Analysis of The Teacher Talks in Teaching Speaking Procedural Text for The Seventh Graders of MTs Salafiyah Syafi'iyah Seblak Jombang. RETAIN, 3(2).

Munawir, A. (2017). The Influence of Teacher Talk toward Students' Attitude to Speak English. ELT WORLDWIDE, 4(1), 27-43.

Nemani, F., \& Rasekh, A. E. (2013). Investigating the Effect of Social Variables on Speech Variation: Social Class, Solidarity, and Power. Journal of Education, Society and Behavioural Science, 300-334. 
The Effects of Lecturers' Formal and Informal Talks on Students' Understanding of the Material in the Language Learning Process

Richards, J. C., \& Schmidt, R. W. (2013). Longman dictionary of language teaching and applied linguistics. Routledge.

Sardi, A., Haryanto, A., \& Weda, S. (2017). The Distinct types of diction used by the efl teachers in the classroom interaction. International Journal Of Science and Research (IJSR), 6(3), 1061-1066.

Wahyu, W. (2019). Students' Engagement and Interest in Learning Writing through Mind Mapping Technique. IDEAS: Journal on English Language Teaching and Learning, Linguistics and Literature, 7(2).

Wiggins, G., \& McTighe, J. (2018). Understanding by design. Alexandria, VA: ASCD.849-E-Learn, 15-18.

Wiske, M. S., \& Breit, L. (2013). Teaching for understanding with technology. John Wiley \& Sons.

Wolf-Wendel, L., Ward, K., \& Kinzie, J. (2009). A tangled web of terms: The overlap and unique contribution of involvement, engagement, and integration to understanding college student success. Journal of College Student Development, 50(4), 407-428.

Xiao-Yan, M. A. (2006). Teacher talk and EFL in university classrooms. Unpublished Master's Thesis, Chongqing Normal University \& Yangtze Normal University, China, 5-13. 